\title{
A Study on Seasonal Variation of Bell's Palsy in a District Area of Bangladesh
}

\author{
Panchanan Das"1, Nazmul Hasan Chowdhury², Md Abdullah Al Hasan³, \\ Mohammad Abul Kalam Azad ${ }^{4}$, A.N.M.Ilias ${ }^{5}$
}

\begin{abstract}
:
Introduction: Bell's palsy is a common cranial neuropathy causing acute onset of unilateral lower motor neuron type of seventh cranial nerve palsy that result in ipsilateral facial muscle weakness. The aim of this study was to determine the possible correlation of Bell's palsy and seasonal influence in a district area of Bangladesh. Materials \& Methods: This is an observational study in which we collect, compiled and analyzed the patients information who attended in outpatient department of neuromedicine unit at Cumilla medical college hospital Cumilla from January 2018 to December 2019. Results: In our study, out of 214 patients male were $117(54.7 \%)$ and female were $97(45.3 \%)$. Age range from 4 to 90 yrs, median age was $40.0 \pm 17.6$ Number of patients with Bell's palsy presented in various seasons include $44 \%$ during winter, 35\% during summer, 9\% during fall monsoon and 12\% during autumn period. We analyzed the data by using Mean $\pm S D$ and chi-square test. A significant association was evident in winter and summer season $(P=0.04$ and $P=0.045)$ respectively. Conclusion: In our present study we found significant relation between seasonal variation and occurrence of Bell's palsy.
\end{abstract}

Key words: Bell's palsy, facial paralysis, seasonal variation.

Number of Tables: 02; Number of Figures: 04, Number of References: 20; Number of Correspondences: 03.

*1. Corresponding Author: Dr. Panchanan Das

Associate Professor

Department of Neurology

Cumilla Medical College, Cumilla.

E-mail: panchanandas10@yahoo.com

Mobile no: +8801718331275

2. Dr. Nazmul Hasan Chowdhury

Associate Professor

Department of Neurology

Cumilla Medical College, Cumilla.

3. Dr. Abdullah Al Hasan

Assistant Professor

Department of Neurology

Cumilla Medical College, Cumilla.

4. Dr. Mohammad Abul Kalam Azad

Assistant Professor

Department of Neurology

Cumilla Medical College, Cumilla.

\section{Dr. A.N.M.Ilias}

Assistant Professor

Department of Neurosurgery

Cumilla Medical College, Cumilla.

\section{Introduction:}

Bell's palsy, which was first described by Sir Charleo Bell, is partial or full peripheral nerve paralysis which has an acute onset, is idiopathic and generally involves only one side of the face ${ }^{1}$. The annual incidence 11.5-40.2/100,000 in the general population ${ }^{2}$. Bilateral involvement is seen in $0.3 \%$ of Bell's palsy patient ${ }^{3}$. Though it is seen at all age, but most frequent in the 15-40 years of age group ${ }^{4}$. While the cause of Bell's palsy remains unknown, a reactivation of latent herpes viruses (HSV-10) in the geniculate ganglia of facial nerve may play an important role in its pathogenesis ${ }^{5}$. In a study of Murakami et al. ${ }^{6}$ DNA of herpes simplex was found on the facial nerve endoneurium of patient diagnosed with Bell's palsy. Bell's palsy is seen more frequently in Germany in winter season, this fact support this hypothesis. It is assumed that with vasomotor changes in a facial region exposed to cold leads to partial ischemia in facial nerve and initiate inflammation around the nerve. Cold air again more easily reactivates the latent remaining viral infection ${ }^{7,8}$. Bell's palsy is a clinical diagnosis and its features reaches peak by $72 \mathrm{~h}^{9}$. It's differential diagnosis are broad and the rate of misdiagnosis by initial consulting physician is $10.8 \%{ }^{10,11}$. Associated symptoms of neck, mastoid or ear pain are usually support the diagnosis ${ }^{12}$. PCR have failed to demonstrate any consistent correlation between viral load and clinical features ${ }^{13,14}$. Though MRI has limited value as diagnostic tool but NCS can predict degree of recovery ${ }^{15}$. The aim of the study was to evaluate the relationship of seasonal variation of Bell's palsy in a district area like Cumilla of Bangladesh.

\section{Materials and Methods:}

This retrospective observational study was made of 214 patients who were presented with facial paralysis at the neurology outpatient department of Cumilla medical college hospital from the period of January 2018 to December 2019. In this study Bell's palsy was defined as the acute disorder of the facial nerve which may begin with symptom of pain or discomfort in the ear and the mastoid region, by hypersensitivity to noise, decreased tear production, reduced taste in the affected side of the tongue and full or partial paralysis of one side of the face ${ }^{16}$. The condition is diagnosed after other possible cause of facial weakness has been ruled out. Patient were excluded if they had chronic ottitis media, facial palsy developed after trauma, mass in the parotid region, surgery in this area, such as acoustic neuroma involve the 
facial nerve. The age and gender of the patient were evaluated separately according to the month and season in which facial paralysis are seen. Seasons were classified as winter (December to February), summer (March to May), fall (June to august) and autumn (September to November) according weather bureau of Bangladesh. All data are calculated by percentage, mean \pm S.D and chi-square test and statistical analysis were done by SPSS version 22 .

\section{Results:}

Table I show, out of 214 cases with Bell's palsy comprised $117(54.7 \%)$ male and $97(45.3 \%)$ female with a mean age was $40.0 \pm 17.6$ and male female ratio was 1.5:1.Most of the person affected at the age of 21 to 30 years and mean percentage was $24.30 \%$. In our study showed number of cases increases from December to March and peak was in January. Bell's palsy presented $44 \%$ in winter, $35 \%$ in summer, $12 \%$ in autumn and $9 \%$ in fall. Cases are increases in winter and summer seasons which were statistically significant $(\mathrm{P}=0.04$ and $\mathrm{P}=0.045)$ respectively.

Table-I: Distribution of the study patients by age $(n=214)$.

\begin{tabular}{ccc}
\hline Age (years) & Number of patients & Percentage \\
\hline$\leq 10$ & 3 & 1.4 \\
$11-20$ & 30 & 14.0 \\
$21-30$ & 52 & 24.3 \\
$31-40$ & 43 & 20.1 \\
$41-50$ & 32 & 15.0 \\
$51-60$ & 27 & 12.6 \\
$61-70$ & 16 & 7.5 \\
$71-80$ & 8 & 3.7 \\
$>80$ & 3 & 1.4 \\
\hline $\begin{array}{c}\text { Mean } \pm \text { SD }=40+17.6 \\
\text { Range }=4.0-90.0\end{array}$ \\
(min-max) \\
\hline
\end{tabular}

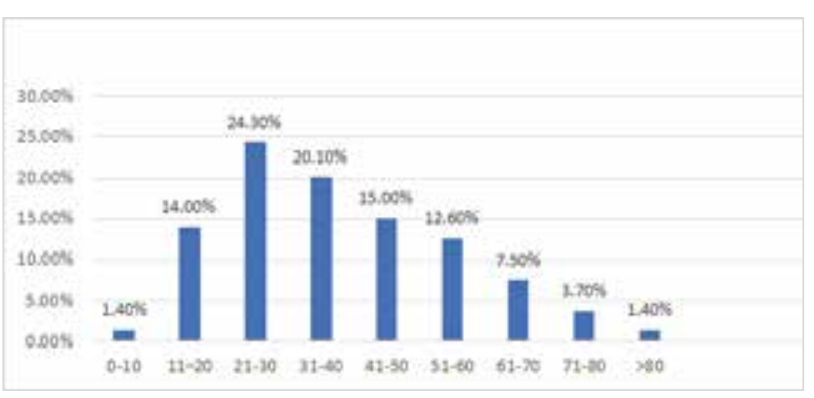

Figure-1: Distribution of age $(n=214) . \quad n=$ number of patient

Table-II: Distribution of the study patient by sex.

\begin{tabular}{lcc} 
Sex & Number of patients & Percentage \\
\hline Male & 117 & 54.7 \\
Female & 97 & 45.3 \\
\hline
\end{tabular}

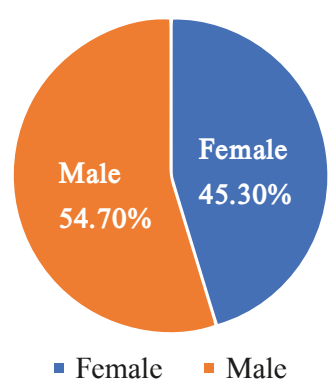

Figure-2: Distribution of the study patients by sex.

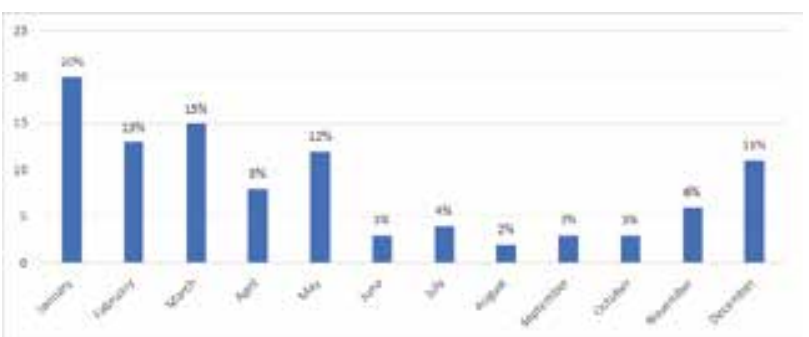

Figure-3: Number of cases of Bell's palsy according to month.

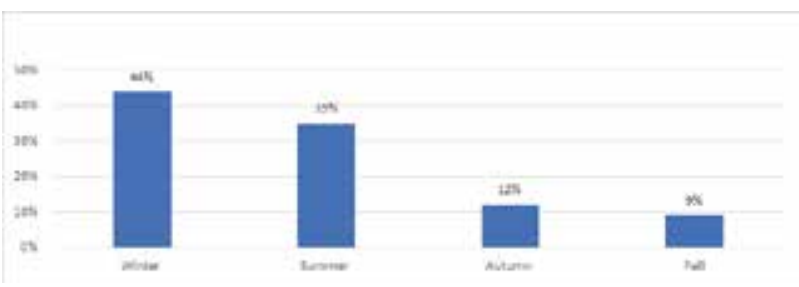

Figure-4: Number of cases of Bell's palsy according to season.

\section{Discussion:}

The most common type of Idiopathic facial paralysis or Bell's palsy is peripheral facial palsy which is typically self-limiting, has an acute onset and affects all the muscle groups of only one side of the face ${ }^{17}$. The study showed that out of 214 cases mean age distribution was $40 \pm 17.6$ and peak incidence was 3 rd to 5 th decade. Sex distribution showed male 117(54.7\%) and female 97(45.3\%) and male female ratio was 1.5:1 Hebun Erdur et al \& Ru-Lan Hsieh et al. assure that mean age of patient was $(49.2 \pm 18)$ and $(43.1 \pm 16)$ respectively and incidence of Bell's palsy rises among male and younger patient which is similar to our study. The presentation of Bell's palsy differed according to months with highest likelihood in December to March and the lowest in June to October. On average 44\% presented in Winter (Dec. to Feb.), 35\% in Summer (March to May), 9\% in Fall (June to August) and 12\% in Autumn (Sept. to Nov.) respectively. There was statistically significant in Winter and Summer season $(\mathrm{P}=0.04$ and $\mathrm{P}=0.045)$. Karen $\mathrm{E}$. Campbell and Brundage ${ }^{18}$ showed that the incidence of Bell's palsy was higher in cold and dry environment than in wetter or warm environment. Leibowitz ${ }^{19}$ showed that high incidence of Bell's palsy occurred more frequently in younger patients during the cold seasons and older patients during the warm seasons. Spengos et $\mathrm{al}^{20}$ showed that Bell's palsy incidence was lower in the Summer and higher 
in the Autumn and Winter seasons and the month with the highest incidence was January. In a study Hsieh et al, which was conducted in the sub tropical climate of Taiwan, no statistically significant difference was determined between the seasons but when age sub groups were examined there was statistically significant in the incidence of Bell's palsy in cold season in those aged less than 50 years. In the current study the highest incidence of Bell's palsy was determined in the Winter seasons especially in the month of December to February. This environmental factor causes acute respiratory tract infections possibly by reactivating latent virus infections. However the findings of other studies investigating seasonal variation of Bell's palsy are heterogeneous and discrepancies may be due to the geographic and climate area where the study was conducted. Limitations of our study include the hospital based and low number of cases per season which precluded a statistical analysis of variation of seasonal incidence across the study period.

\section{Conclusion:}

We assessed the association of seasonal variation of Bell's palsy among a district area of Bangladesh. Our study showed that during the winter season the incidence of Bell's palsy increased among men and younger population in Bangladesh. Prospective study with a large sample size is to be required for more confirmation of our findings.

\section{Conflict of Interest: None.}

\section{Acknowledgment:}

The authors are thankful to the study subjects for their active, sincere and voluntary participation. The authors are also grateful to all teachers and stuff of Department of Neurology, Cumilla Medical College and also thanks to Md. Nuruzzaman Hossain for his assistance in the analysis of data in this study.

\section{References:}

1. Baugh RF, Basura GJ, Ishi LE, et al. Clinical Practice Guideline: Bell's Palsy. Otolaryngol Head and Neck Surg. 2013; 149:1-27.

https://doi.org/10.1177/0194599813505967

PMid:24189771

2. De Diego JI, Prim MP, Madero R, et al. Seasonal patterns of idiopathic facial paralysis; a 16-year study. Otolaryngol Head Neck Surg 1999;120:269-71.

https://doi.org/10.1016/SO194-5998(99)70418-3

PMid:9949364

3. Hsieh RL, Wang LY, Lee WC. Correlation between the incidence and severity of Bell's palsy and seasonal variations in Taiwan. Intern J Neuros 2013;123:459-64.

https://doi.org/10.3109/00207454.213.763804

4. Tovi F, Hadar T, Sidi J, et al. Epidemiological aspects of idiopathic peripheral facial palsy. Eur J Epidemiol 1986;2:228-32.

https://doi.org/10.1007/BF00211536

PMid:3792520
5. Erdur HE, Ernest ST, Ahmedi MI, et al. Evidence for Seasonal Variation of Bell's Palsy in Germany. Neuroepidemiology 2018;51:128-130.

https://doi.org/10.1159/000492097

6. Murakami S, Mizobuchi M, Nakashiro Y, et al. Bell's palsy and herpes simplex virus: identification of viral DNA in endoneurial fluid and muscle. Ann Intern Med. 1996;124:27-30.

https://doi.org/10.7326/003-4819-124-1_part_1-1996 01010-00005

PMid:7503474

7. Yanai O, Unno T. Relationship between idiopathic peripheral facial paralysis and climate. Acta Otolaryngol 1988;(Suppl.446):27-9.

https://doi.org/10.3109/00016488709121837

PMid:3166584t

8. Yilmaz NE, Gur OZ, Kucuktepe U, et al. Seasonal distribution of the incidence of bell's palsy. Mediscience, 2019;08:750-53.

https://doi.org/10.5455/medscience.2019.08.9053

9. Timothy J Eviston, Glen R Croxon, Tessa Hadlock, et al. Bell's palsy: aetiology, clinical features and multidisciplinary care. J Neurol Neurosurgery Psychiatry 2015;86:1356-1361.

https://doi.org/10.1136/jnnp-2014-309563

PMid:25857657

10. Hohman MH, Hadlock TA. Etiology, diagnosis, and management of facial palsy: 2000 patients at a facial nerve centre. Laryngoscope 2014; 124: E283-93.

https://doi.org/10.1002/lary.24542

PMid:24431233

11. Croxson G, Coulson SE, Mukherjee P. Mistaken diagnoses in facial nerve disorders[conference presentation]. 12th International Facial Nerve Symposium. Boston: 7 a June 2013.

12. Canalis RF, Cino L. Ceramic representations of facial paralysis in ancient Peru. Otol Neurotol 2003; 24:823-31.

https://doi.org/10.1097/00129492-200309000-00023

PMid:14501464

13. Steiner I, Kennedy PG. Molecular biology of herpes simplex virus type 1 latency in the nervous system. Mol Neurobiol 1993;7:137-59.

14. Stjernquist-Desatnik A, Skoog E, Aurelius E. Detection of herpes simplex and varicella-zoster viruses in patient with Bell's palsy by the polymerase chain reaction technique. Ann Otol Rhinol Laryngol 2006;115:306-11.

https://doi.org/10.1177/000348940611500410

PMid:16676828

15. Gantz BJ, Rubinstein JT, Gidley P, et al. Surgical management of Bell's palsy. Laryngoscope 1999;109:1177-88. 
https://doi.org/10.1097/00005537-199908000-00001

PMid: 10443817

16. Adour KK. Diagnosis and management of facial paralysis. N Engl J Med 1982; 207:348-51.

https://doi.org/10.1053/NEJM198208053070605

17. Gilden DH. Bell's palsy. N Engl J Med 2004;351:1323-31.

https://doi.org/10.1056/NEJMcp041120

18. Campbell KE, Brundage JF. Effects of climate, latitude, and season on the incidence of Bell's palsy in the US Armed
Forces, October 1997 to September 1999. Am J Epidemiol 2002;156:32-9.

https://doi.org/10.1093/aje/kwf009

19. Leibowitz U. Bell's palsy - two disease entities? Neurology 1966;16:1105-9.

https://doi.org/10.1212/wnl.16.11.1105

PMid:5950921

20. Spengos K, Sameli S, Stouraitis G, et al. Seasonal variation of Bell's Palsy in Athens, Greece- a hospital-based retrospective evaluation over fifteen years. European Neurol. 2.2006;55:84-88.

https://doi.org/10.1159/000092779 